ازمة الهوية للعرب الاميركان في رواية الكاتبة ليلى حلبي مرة واحدة في الارض الموعودة

مدرس: حنان عباس حسين

جامعة بغداد-كلية التربية للبنات_قسم اللغة الانكليزية

هاتف: VV .

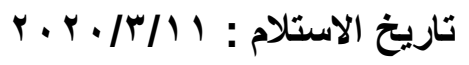

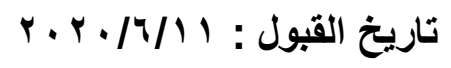

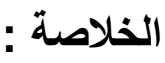

تهدف هذه الدراسة إلى وصف أزمة هوية أهالي الثتات (العرب الأمريكان) في رواية ليلى حلبي مرة واحدة في أرض الوعد. حلبي تتناول قضايا العنصرية والإقصاء وعدم ثبات الهوية التي أثرت على الهتمع العربي الأمريكي بعد الحدث الإرهابي في الحادي عشر من سبتمبر . ألقت الضوء على تجارب شخصياتها الرئيسية سلوى وجاسم في أمريكا ، موضحة كيف أضعف هذا الحدث وضعهما الاجتماعي وجعل وجودهما في أمريكا مسألة. تصف مرارة شخصياتها التي تستحث على حلم الانتماء إلى أرض تستبعد ثقافتها الأصلية وقيمها الدينية فضلاً عن لغتها. حلبي توضح أن العيش في أمريكا ينطوي على تحديات لمواجهة المضايقات والتعدي اللفظي. تكثف فثل سلوى وجاسم في تجاوز سياسة الخوف والأفعال العدوانية الأمريكية التي ساعدت في

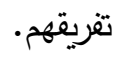
الكلمات المفتاحية: الهوية، استبعاد، العرب الامبركان، المضايقات 


\title{
Identity Crisis of Arab - American in Laila Halaby's Novel Once in a promise Land
}

\author{
Instructor: Hanan Abbas Hussein \\ University of baghdad \\ College of education for women \\ Department of english
}

hananiraq_84@yahoo.com

\begin{abstract}
This study aims at describing the identity crisis of Diaspora people (Arab -American) in "Laila Halaby's" novel "Once in A promise Land". Halaby tackles the issues of racism, exclusion, and instability of identity that affect the Arab American community after the terrorist event of eleventh of September. She sheds light on the experiences of her significant characters Salwa and Jassim in America, clarifying how this event weakened their social position and turns their presence in America questionable. "Halaby" describes the bitterness of her characters who are induced into a dream of belonging to a land that transcends their original culture and religious values as well as their language. "Halaby" explains the subsistence in America involving challenges to face the harassment and verbal transgression. She reveals the failure of Salwa and Jassim to transcend the policy of fear and aggressive acts of America which help in dispersing them.
\end{abstract}

Keywords: Identity, Exclusion, Diaspora, Arab-American, harassment. 


\section{1- introduction}

Diaspora is considered as the main phenomenon of postcolonial era in its essence. Diaspora (in Greek) means the movement of peoples from their homelands into new regions. The term 'Diaspora' refers to the people who are separated from their national territory and have a hope or a desire to return to their homeland. (Donlald, 2005, p.559) It focuses on the real movement of peoples throughout the world, noticing these migrations may be done willingly or obligatory. "James Sprocter" writes " 'Diaspora' can appear both as naming a geographical phenomenon- the traversal of physical terrain by an individual or a group- as well as a theoretical concept: a way of thinking, or of representing the world"( McLeod, 2008, p.5). Therefore, Diaspora does not only explain the geographical dispersal but it also refers to the vexed questions of identity, home and memory that displacement will produce. "Robin Cohen" describes Diaspora as communities of people living together in one country who acknowledge that the native country is a notion buried deep in religion, custom and language, and he explains their loyalty and emotions to the old country. (Ibid) In fact, the past is always with us and defines our present." The past is merely a function and production of a continuous present and its discourse". (Hirsch and Valerie Smith, 2002, .p.9)

Diaspora communities suffer from the problems of exclusion i.e. the feeling of not belonging to the 'new country'; they think that their cultural practices are being deceived or discerned. As "Said" states " most people are principally aware of one culture, one setting, one home, exile are aware of at least two, and this plurality of vision gives rise to an awareness of simultaneous dimensions, an awareness that to borrow a phrase from music-is-contrapuntal"(Edward Said , 2000.p.186).'Arab-Americans' is a term referring to Arab Muslims and non-Muslims who 
migrated from their homeland willingly or reluctantly to the United States. Those people migrated from east particularly Palestine, Lebanon and Syria, carrying with them their religion and past. Living in America forces them to adopt a new culture and identity. Diaspora peoples 'ArabAmericans' are not always liked into the new country as "John McLeod" states "Diaspora people often remain ghettoized and excluded from feeling they belong to the 'new country' and suffer their cultural practices to be mocked and discriminated against"( McLeod, 2008, p.239). In the United States 'Arab- Americans' are excluded from being 'American' because they have different culture and religion. Diaspora people 'Arab- Americans' migrate from their homeland to America in order to seek for jobs, education and refuge. Unfortunately, they are trapped in a state of a loss of stability and freedom. They live in-between and suffer from the pains of non-belonging. "Homi Bhabha" defines the in-between space as "emergence of the interstices -the overlap and displacement of domains of difference-that the inter-subjective and collective experiences of nationness, community interests, or cultural value are negotiated" (Bhabha, 1994, p.2). Living inbetween past and present, inside and outside, Arabian identity and American one is considered as a struggle because people in nature find difficulty to indulge in sentiments of belonging to either place .( McLeod, p.214-217)

As a result, the concept of identity arises among 'Arab-Americans' after the event of the eleventh of September terrorist attacks. Themes of displacement, and discrimination against Arabs and Muslims in America dominate the majority of texts as "Pauline Kaldas" comments:

"Post-September 11, the invasion of Afghanistan, the extralegal treatment

Of Arab American [and] the war on Iraq must be considered turning point,

Not only for the community but also for the larger American public's awareness of the community's existence. Arab American could not try to engage the world 
and remain anonymous".( Conrey \& N. Fadda, 2007,p.59).

We can see how 'Arab-Americans' are deeply affected by the event. They authenticate the stereotypes and they living in a sort of bitterness although they try to restore the image that has been damaged by fanatic acts as "Steven George Salaita" states "it has proved challenging to develop one in response to an event that so drastically affected the makeup of Arab American community"(Salaita, 2005, p.146) .The event of eleventh of September represents a turning point in the life of Arab community in America which arises the feeling of belonging and identity. Most Arab writers who live in America deal with issues of identity, trying to depict that Arabs who immigrated to the United States search for better life without harming people who had been already living there. Arab-American writers who are in the presence of this situation speak their minds in the favor of Arabs. These writers swing back and forth between their cultural heritage and American cultures. "Lisa Suhair Majaj" states that "contemporary Arab-Americans literature increasingly reflects the awareness of the need to forge connections beyond the insular boundaries of group identity" (Majaj, 1999, p.326). "Majaj" believes that literature is an effective way to reflect the situations of 'Arab-Americans' in the United States. Among those Arab American writers is "Laila Halaby" (1966- ) who lives in America and she is aware of the problems of Arabs after the eleventh of September. She illustrates the difficulties that face Arab migrants in America.

\section{2- Discussion}

"Halaby's" novel 'Once in a Promise Land' (2007) is the story of Salwa and Jassim, an immigrant Jordanian Muslim couple, who lived and worked in Tucson, a city of few kilometers from New York. Jassim works as a Hydrologist and his wife Salwa works as a banker. They leave the deserts of their native Jordan to United States to fulfill their quintessential dreams. After the terrorist event of eleventh of September, their life is changed. They cannot escape the racial discrimination 
of the American citizens and FBI agents. Jassim's work as a Hydrologist being surrounded by WASP colleagues like Corey, Bella, and Lisa who conspire against him leads the FBI to suspect him of being a terrorist. His colleagues keep him under constant observation, checking his computer and continuously noting down his statements. All these things help to put Jassim in the hands of FBI. Halaby describes the FBI questions of Jassim as the rich man from the Middle East, highlighting the hate, prejudice, and hostility among the FBI agencies. After the eleventh of September FBI interrogates Jassim he tells them:

"I am a scientist; I work to make water safe and available. I am

a normal citizen who happens to be an Arab. Yes, I have access

to the city's water supply, but I have no desire to abuse it. The mere

fact that I am an Arab should not add suspicion to the matter. I have

spent my entire life trying to find ways to make water safe and accessible

for everyone. Just because I was raised a Muslim, you

want to believe that I am capable of doing evil".( Halaby, 2007, p.232).

"Halaby" explains how the terrorist event changes the life of her main characters Jassim and Salwa. She elaborates how they live as a pure American product with no link with their homeland except for the family relationship. Jassim and Salwa adopt an American way of life to complete their life peacefully. This is reflected in Jassim's system of life which becomes distant from the origin system:

"Jassim delighted in the stillness the morning offered, a time before emotions were awake, a time for contemplation. This day was no exception as he got teeth, and relieved himself, the beginning of a morning ritual as close to prayer as he could allow. His thoughts hovered over the internal elements of self and world rather than 
the external. Jassim did not believe in God, but he did believe in balance. At five o'clock

with day still veiled, Jassim found balance".( Halaby,2007, p.3).

Unfortunately, this peaceful life of the couple is changed after the tragic event of eleventh of September. They face harassment and suspicion everywhere. Such harassment are shown when the couples are in the shopping center where Salwa is busy choosing garments and Jassim's eyes falling on motorcycle parked in front of the shopping center. Suddenly Salwa notices a woman following her husband; Salwa inquires the woman why she is following her husband. The woman answers her that a salesman has informed her that one of the Arabs is looking on a motorcycle, as if he wants to steal the whole shopping center and run a way. Salwa tells Amber (a sale clerk at the mall):

"I am sorry to hear that. Are you planning to have every

Arab arrested now? ... Do you not use our brains?

This country has more than fifty million people in it and you 're worried about your tacky little store.

But now you will have a lot talk about in school.

You can say you saw a real live Arab and had to call security on him".( Halaby,2007, p.30).

Salwa and Jassim give an excuse for a girl who suspects Jassim because the girl's family has been killed in a terrorist attack of the eleventh of September. The girl develops a great fear of the whole Arabs in America. Therefore, the harassments followed Salwa and Jassim; one day while Salwa and Jassim are shopping in a store they are seized by a terrorist phobia. Thus, snipers are placed on the roof and the staff gives instructions to warn about any suspicious activity when they receive. In this situation: 
"Salwa eyes were on her husband at first but gilded over to land behind him on the security guard puffed up and close to bursting out her uniform...."is there a problem?'

Salwa asked in English over her husband shoulder."No Ma'am" "Then why are you following my husband?" "I'm doing my job, Ma'am" "Which is exactly?" asked

Salwa with opened scissors in her face. To protect the security of this establishment"

"And how you are doing that by following my husband?"(Halaby,2007, p.29)

At first, Jassim convinces himself that his position as a senior minimizes the aggressive acts but later he discovers that he is totally wrong. He becomes astonished that "for the first time he felt unsettled in his beloved America, vaguely longed for home, where he could nestle in the safe, predictable bosom of other Arabs"(Halaby, p.165). He understands the events of unjustified interrogation and he begins to take into consideration the world surrounding him. He realizes that his dream of better life in America is "like a ghost who might vanish at any time without being noticed"(Halaby, p.57). Prejudice and discrimination are shown in Salwa's place of work, Salwa is treated badly by the American customer who comes to the bank to open an account. As she hears that Salwa is a Palestinian from Jordan, she treats her with anger and arrogance asking Salwa:

"What does that mean?

What do you mean that you are Palestinian from Jordan? Does it mean you will steal my money and blow up my world?".(Halaby, p.113).

These aggressive acts help in increasing Salwa's feeling of the injustice treatment of American's community and considering it as harsh and unkind. She becomes nervous and over reacts to any unfriendly acts. In fact Salwa has a strong personality unlike her husband who appears as helpless and unable to defend Salwa from the aggressive acts saying:"Salwa, I am sorry 
it has come to this. For what happened. I feel that I am responsible"(Halaby, p.326). The couple understand that the American dream which they had been living become an illusion .They are put in a position either to go back to their homeland or to challenge the situation.

Obviously, Halaby tries to illustrate the injustice acts aftermath the eleventh of September against the Diaspora people 'Arab-Americans' and denouncing the racial discourse in America. She reveals the dilemma of identity construction of her major characters Jassim and Salwa. The couple tries to live comfortably but the atmosphere of displacement outside in places of work causes a lack of communication between them. The racial profiling and harsh realities weaken their relationship, Salwa and Jassim turn away from each other. Salwa keeps several secrets from her husband and becoming pregnant against his will, but she is consumed by an eventual miscarriage. For Jassim, he finds the company with an American waitress named Penny a solution to soften his isolation especially after his car accident. Salwa and Jassim are guilty for betraying the familial bonds which leads to their isolation. When Salwa tells him her decision to go back to Jordon without him, he realizes that a gap between them might lead their relationship to the end:

"In leaving out what was most on his mind, Jassim realized they had

spent their lives together not saying what mattered most , dancing around the peripheries instead of participating. We had seen in her a passion and excitement for life that had become dulled almost immediately upon their arrival in the United States.

What he wanted in her couldn't exist in America, couldn't

Exist with him".(Halaby, p.303)

In fact, Salwa and Jassim embody Arab Immigrants dilemma. They are ready to follow American's system of life without erasing their identity and Arab heritage. Salwa accepts the 
American flag on her car which given to her by American friend to avoid the racist attacks. Although she has three nationalities Jordan, Palestinian and American but she feels rootless with original land.

Halaby reveals that Salwa's birth in America is a malediction. She says" Salwa hadn't fully realized yet was that in breathing her first breath on America soil, she had been cursed"(Halaby, p.49). She gives a full description of this voluntary exile:

"Because while place of birth does not alter genetic materials, It does not stitch itself under the skin and stay attached by virtue Of invisible threads, so that if a person leaves that place for Somewhere else (whether because she's been kicked out and Forcibly sent away or because she is simply returning to the Home of her parents, there is always an uncomfortable tugging As the silken (in her case) threads are pulled taut".(Halaby, p.49) "Halaby" sums up the complex situation of the main character of her novel (Salwa). She explains how 'Arab- Americans' try to build their own identity but they remain fragile and strongly connected to their origins. The issue of identity crisis is a problematic especially after the tragic events of the eleventh of September which deepen the racism and discrimination among them. Arabs are rejected to live in America freely like other ethnicities. This attitude can be seen clearly in different episodes especially the sexual affairs between Arab women and American men which later turn into aggressive attack which reinforces that Arab ethnicity is no longer acceptable inside the United States. Therefore, America becomes a symbol of failure for Arabs who search for a better life. 
"Halaby" illustrates how Salwa adheres to her cultural roots. Salwa uses her Arabic language with her Arab friend Randa to clarify her link to her identity. Similarly, Salwa is attracted to her friend, Jake who speaks with her in Arabic language and succeeds to seduce her. He finds Salwa:

"Mature without seeming old. This mixed with her foreignness made her sophisticated, and married. The challenge of this combination turned him on, and he wandered if all Arab woman had this allure (the physical one and the shadow of a man behind them) and if that was why they veiled themselves".(Halaby, p.171).

Salwa likes Jake, finding his attention comfortable to her. She exceeds the limits of her position and sleeps with him; later on she is attacked by Jake when she refused to abandon her marriage. Salwa does not use Arabic language when she informs her friend Randa about her betrayal to her husband, she cannot say or think about it in Arabic. She knows that betrayal in their culture is taboo, refusing to say it in her mother tongue. Even when she tells Randa about her friendship with a man, she changes her language then switches back to Arabic to say something else. Becoming a friend with a man for a married woman is something unacceptable in their culture. She should show their loyalty to their marriage, which is considered unimportant in American culture.

As for Jassim he uses both Arabic and English languages, for instance when he tries to associate with Penny (a voluptuous American's waiter), he chides himself in English:" what in God's name, on God's earth, am I doing? He asked himself loud in English"(Halaby, p.159). But he uses Arabic language to cancel the date with Penny saying:" I can't do this; he said a loud in Arabic"(Halaby, p.160).Jassim considers the distance between himself and Salwa as a reason behind his betrayal and justifies his relationship to Penny by considering it as a consolation after 
his a car accident. Halaby reveals that Arabs feel shame to talk about things related to sexual matters or even their personal life issues. She indicates these things unbearable for Arabs. Halaby focuses on using English language to make Americans familiar with Arab culture, religion, language, ideas and also showing false ideas about Arabs. She intends to make reader believe the superiority of Arabs in some cases. In addition, she says that the clash between the different cultures and values affects the psyche of immigrant's people.

Once again, in an attempt to show how her characters are attached to their Arabic identity, Halaby explains that Salwa and Jassim have the tendency to eat Arabic food. Salwa prepares baklava which is considered as a typical Arabic food. Nine years in America is not enough to omit the memories of their past. Salwa always praises the Arabic coffee that is prepared by her closet friend Randa, she says" the coffee boiled a way thousands of miles of home sickness"(Halaby, p.284). In spite of the feelings of homelessness and displacement, food considers as a bridge for communal life among Arab Americans.

Being an Arab Muslim was defined as being a terrorist, "Edward Said" states" Islam as a kind of scapegoat for everything we do not happen to like about the world's new political, social, and economic patterns. For the right, Islam represents barbarism; for the left, medieval theocracy; for the center, a kind of distasteful exoticism" (Edward Said, 1997, p. 12). Unfortunately, Media plays a negative role and aggravates the ideas of discrimination and racism among 'ArabAmericans'.

American's Media shares in escalating the images of animosity and bellicosity among Arab and American. "Halaby" describes that Media contributes in the lack of differences especially after the terrorist attack. One day Salwa returns from her work in her car, she:

"Stopped at a red light with her window closed against 
The unbearable heat, which seemed as though it would

never, ever end. She pressed the forward scan button

on the radio, searching for the station with soft rock

and no commercials . A man's voice blared out:" is

anyone fed up yet? Is anyone sick of nothing being

done about all those Arab terrorist? In the name of

Jesus Christ! They live with us. Among us!

Who are just want" (Halaby, p.56).

'Arab -Americans' are victims of generalization, physical assaults, and racial profiling. They try to build their life with new identity as other minorities like Turks and Iranians but they face rejection in a hostile environment. Psychoanalytically speaking, 'Arab- Americans' search for identity to find the fantasized pleasure for themselves. The journey of identity formation may create the confusion as "Stuart Hall" states:

"Cultural identity is a matter of 'becoming' as well as of being.

It belongs to the future as much as to the past. It is not something which already exists, transcending place, time, history and culture.

Cultural identities come from somewhere, have histories. But, like everything which is historical, they undergo constant transformation.

For being eternally fixed in some essentials past, they are subjects

to the continuous 'play' of history, culture and power".( Hall, 2019)

"Halaby" explains that Americans regard themselves as global citizens while Eastern and Western cultures remain alienated and estranged. She portrays American society as a conspiratorial ghula (a female demonic figure of Arabic folklore)who lures her victims to private place and eats them, 
explaining that America is considered as a threat to 'Arab -Americans' especially her major character Salwa by pulling her away from familiar world , customs and destroying her:

"The hairy ghula saw the beauty in child's face and grew madly

Jealous, wanted the baby for her own, but knew she wouldn't

Get past security, so she took out her wild ghula threads and began

to stitch them under the baby's skin...[w] hen the ghula was done, the

baby lay asleep with a thousand and on red threads hanging from her

...[w]hen the ghula thought the girl would be grown and ripe for eating,

she began to reel in remaining threads, pulling her from her familiar world,

gently turning the skein a bit more each day".(Halaby, p.331).

Using the fairy tale in her novel represents a nationalist indication. Through her experience, "Halaby" emphasizes the impossibility of achieving an equal life with American's community and Arabs who want to assimilate they remain outsiders.

\section{3- Conclusion}

"Halaby" portrays the issue of identity crisis by examining her major characters Jassim and Salwa in her novel Once in a promise Land. She illustrates the psychological injures left on her characters by American hostility. She introduces different episodes that confronted by Jassim and Salwa in public places to explain the displacement and discrimination into the American society on Arabs especially after tragic event of the eleventh of September. She highlights the feeling of 'in-betweens' that is felt by Salwa and Jassim that makes the representation of identity into American society quite random. Halaby provides unhappy endings for Jassim and Salwa who seek salvations to their existential deadlock, clarifying that the desire of co-existing requires patience and challenge to live in a new society with different culture and facing the jeopardy. She 
describes the aggressive policy of America after the terrorist event of eleventh of September which leaves a wound in the psyche of her protagonists and revealing their failure to transcend their intrinsic handicap.

\section{References}

Bhabha, H. (1994). The Location of Culture. London: Routledge.

Convey, C. \& Fadda, N. (2007) Writing Arab-American Identity post 9/11, ed. Dima Dabbou. Beirut: Lebanese American University.

Donald M. Noini (2005). Encyclopedia of Diaspora, Ed. Melvin Ember, Carol R., and Ian Skoggard. USA: Springer.

Edward, D. Said. (2000). Reflections on Exile and other essays, Cambridge, Massachusetts: Harvard University press.

Edward, D. Said. (1997).Covering Islam: How the Media and the Experts Determine how we see the rest of the world. London: Vintage Books.

Halaby, L. (2007). Once in a Promise Land. Boston, MA: Beacon Press.

Hall, S. (2019). Cultural Identity and Diaspora.

(URL:http//www.unipa.it/-michele.cometa/hall_cultural_identity.pdf.

Harisch, M. \& Smith, V. (2002). Feminism and Cultural Memory: an Introduction.Vol.28.No1. (URL:http://www.jstor.org/stable/10.1086/340890). 
McLeod, J. (2008). "Diaspora and Utopia", Diaspora Literature and Theory-Where Now? Ed. Mark Shackleton. UK: Cambridge Scholars Publishing.

Salaita, S. George. (2005). Ethnic Identity and Imperative Patriotism: Arab Americans Before and After 9/11.Colleege Literature. Vol.22:2.

Suhair, L. Majaj. (1999) Arabs-Americans Ethnicity: Location, coalitions, and cultural Negotiations. "Arabs in America: Building a new future. Ed. Michael W. Suleiman. Philadelphia: Temple Up. 